\title{
Role of liquid-based cytology and cell block study of pleural fluid in the evaluation of cases of malignant Pleural effusion with special reference to immunohistochemistry
}

\author{
Saha R. ${ }^{1}$, Sardar S. ${ }^{2}$, Das S. ${ }^{*}$ \\ DOI: https://doi.org/10.17511/ijmrr.2021.i03.09
}

${ }^{1}$ Rama Saha, Associate Professor, IPGME \& R and SSKM Hospital, Kolkata, West Bengal, India.

2 Samaresh Sardar, Medical Officer (Pathology), Mekhliganj S.D Hospital, Coochbehar, West Bengal, India.

3* Smritiparna Das, Post Graduate Trainee, Department of Pathology, IPGME \& R and SSKM Hospital, Kolkata, West Bengal, India.

Introduction: Lung cancer is the most common primary tumor associated with malignant pleural effusion (MPE). In this study, we aim to use cell remnants for cell block preparation after performing liquid-based cytology (LBC) of effusion fluid. Immunohistochemistry was helpful to evaluate those cases having diagnostic dilemmas in LBC and cell block. Method: It was a cross-sectional, prospective, single institution-based study, conducted in the department of Pathology in collaboration with the Department of Respiratory Medicine IPGMER \& SSKM Hospital, from January 2018 to June 2019 in the institution. Result: Most of the study population were in between the age group of 51 to 60 years with male predominance and with fever and cough being the predominant symptoms. Liquid-based cytology was positive for malignancy in $58 \%$ of cases and suspicious of malignancy in $22 \%$ of cases of malignant pleural effusion and it had $95.35 \%$ sensitivity, $58.82 \%$ specificity in diagnosing malignant pleural effusion.LBC was done followed by cell block preparations are studied further by Immunohistochemistry. Discussion: Morphological features were better identified by the cell block method when compared to LBC. Multiple sections can be obtained for special stain or IHC study which bridges the gap between cytology and histology.

Keywords: Cytological examination, Immunohistochemistry, Lung cancer, Malignant plural effusion

Corresponding Author

Smritiparna Das, Post Graduate Trainee, Department of Pathology, IPGME \& R and SSKM Hospital, Kolkata, West Bengal, India.

Email: smritiparnadas92@gmail.com
How to Cite this Article

To Browse

Saha R, Sardar S, Das S. Role of liquid-based cytology and cell block study of pleural fluid in the evaluation of cases of malignant Pleural effusion with special reference to immunohistochemistry. Int J Med Res Rev. 2021;9(3):185-192. Available From https://ijmrr.medresearch.in/index.php/ijmrr/article/ view/1276
Manuscript Received 2021-04-06

Conflict of Interest No 2021-04-09

Funding $\mathrm{Nil}$

Review Round 2
2021-04-30
Ethical Approval
Yes

Review Round 3 2021-05-10

Plagiarism X-checker $5 \%$

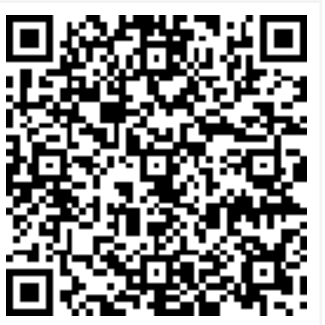

(c) 2021by Rama Saha, Samaresh Sardar, Smritiparna Dasand Published by Siddharth Health Research and Social Welfare Society. This is an Open Access article licensed under a Creative Commons Attribution 4.0 International License https://creativecommons.org/licenses/by/4.0/ unported [CC BY 4.0]. 


\section{Introduction}

Malignant pleural effusion (MPE), a common complication of cancer cell metastasis to the pleura is characterized by the proliferation of cancer cells in the pleura leading to abnormal fluid collection. Lung cancer is the most common primary tumour associated with malignant pleural effusion (MPE). Adenocarcinoma represents the most frequent histologic type of lung cancer to result in a malignant pleural effusion presumably because adenocarcinomas comprise a greater proportion of peripheral cancers than the other histologic types [1]. followed by squamous cell carcinoma, small cell carcinoma, and large cell undifferentiated carcinomas [2]. Great advances in screening have lowered the death rate from lung cancer. The pleural space lies between the lung and the chest wall and normally contains a very thin layer of serous fluid $(15 \mathrm{ml})$ [3]. Normally fluid enters the pleural space from the capillaries in the parietal pleura and is removed via the lymphatics in the visceral pleura. The lymphatics can absorb twenty times more fluid than is formed normally. Accordingly, a pleural effusion may develop when there is excess pleural fluid formation or when there is decreased pleural fluid removal by the lymphatics.

Malignant pleural effusion (MPE), a common complication of cancer cell metastasis to the pleura, is characterized by the proliferation of cancer cells in the pleura leading to abnormal fluid collection, classified as exudates according to Light's criteria [4]. Treatments and prognosis of these diverse pleural conditions vary greatly. Accurate diagnosis of pleural effusion is therefore extremely important. Clinically effusion can be divided into transudative and exudative. Transudative fluid is caused by the disturbance of hydrostatic pressure and/or osmotic pressure. Here the wall of the blood vessels is intact. It has a low specific gravity (less than1.015), low protein content and scanty cellularity [5]. The cells in transudate are usually mesothelial cells and occasional lymphocytes or polymorphs. Its common causes are CCF, cirrhosis of the liver and renal failure. On the other hand, exudate is caused by the damage to the wall of the blood capillaries of the mesothelial lining. This damage may be due to inflammation or direct damage by malignant cells. Exudative effusion has a higher specific gravity (more than 1.015) and high protein content (more than $3 \mathrm{gm} / 100 \mathrm{ml}$ ), high lactate dehydrogenase content, high fibrin and is rich in cells [6].
In this hospital-based cross-sectional observational study, assessment of different clinical and radiological parameters of malignant pleural effusion, detailed analysis of liquid-based cytology of pleural fluid, cell block study of the residual fluid done to reach the etiological diagnosis of malignant pleural effusion. For each pleural fluid specimen liquid-based cytology and cell block preparation were done and stained with Papanicolaou stain (PAP stain) for cytology and haematoxylin and eosin stain for cell block preparation. Cytological examination of pleural fluid was one of the commonly performed examinations and it is not only important in diagnosis but also necessary for staging and prognosis. The diagnostic performance of liquidbased cytology (LBC) of pleural fluid may be attributable to the fact that the cell population present in sediment was representative of a larger surface area and on the other hand cell block study was simple, inexpensive and not required any special training or instrument. Morphological features were better identified by the cell block method when compared to LBC. Multiple sections can be obtained if required for a special stain or IHC study. The immunohistochemical study by TTF-1, NAPSIN A, and P-40 was also done in this study that helped $m e$ for the further categorization of adenocarcinoma, squamous cell carcinoma confirmedly. This is helpful to evaluate those cases having diagnostic dilemmas in LBC and cell block. It will bridge the gap between cytology and histology.

\section{Objectives}

A) To study the pleural fluid in liquid-based cytology preparation followed by Cellblock study for the diagnostic workup of malignant pleural effusion.

B) To study the immune expression and importance of different biomarkers (TTF-1, Napsin A, P-40) in the etiological diagnosis of malignant pleural effusion.

\section{Material \& Methods}

It was a cross-sectional, prospective, single institution-based study, conducted in the department of Pathology in collaboration with the Department of Respiratory Medicine IPGMER\&SSKM Hospital, from January 2018 to June 2019 in the institution. Liquid-Based Cytology (LBC) of pleural fluid and Cell Block study of the same fluid was performed to achieve an etiological diagnosis. A total of 60 patients were evaluated. 
- Inclusion criteria: Patients admitted under Department of Respiratory Medicine with features suggestive of malignant pleural effusion and undergone thoracocentesis having radiological evidence of pleural effusion

- Exclusion criteria: Patients who were not willing to do aspiration and pleural effusion due to haematological malignancies or metastatic pleural disease and seriously ill patients.

For each pleural fluid specimen liquid-based cytology and cell block preparation was done by Thrombin -Plasma method of cell block preparation and stained with Papanicolaou stain (PAP stain) for cytology and hematoxylin and eosin stain for cell block preparation.

\section{Immunohistochemistry}

Thyroid transcription factor-1 (TTF-1): (Catalog no-VLTM3126G20) Expression pattern: Nuclear.TTF1 also known as NKX2-10r thyroid- specific enhancerbinding protein Positive control: thyroid tissue.[7].

Napsin A: (Catalog no-352A-74) (Expression pattern: cytoplasmic. NapsinA is expressed in the majority of pulmonary adenocarcinomas and is used as a specific marker for pulmonary adenocarcinoma. All other primary pulmonary carcinoma types lack the expression of NapsinA.[8].

P40: (Catalog no-ACI3066A, C) Expression pattern: nuclear stain. P40 is immunostaining that is both specific and sensitive for squamous cell carcinoma of the lung. It is considered superior to p63 as it is more specific.[9].

Statistical Analysis: Data was summarized by routine descriptive statistics. An attempt was made to compare the major differential diagnosis of lung neoplasia based on LBC, Cell Block study and Immunohistochemistry.

\section{Results}

The present study includes a total of 60 cases suspected of malignant pleural effusion among which there were 40 male and 20 female patients. The most common age group with malignant pleural effusion were 51 to 60 years. A total of 25 patients ( $41.7 \%$ of the total population) were in this age group. (Figure-1)

Figure-1 Shows Age and sex distribution among total number of patient.

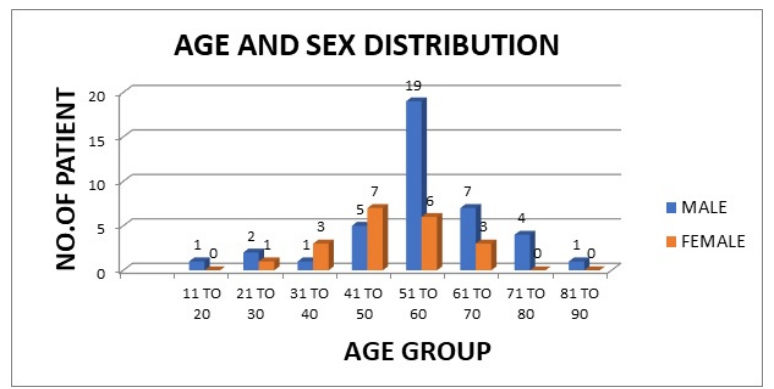

Fever $(85 \%)$, Cough $(83 \%)$ and chest pain $(80 \%)$ were the most common symptoms followed by dyspnoea $(47 \%)$, weightless $(57 \%)$ and haemoptysis $(22 \%)$. In the majority of cases presence of multiple symptoms were seen.

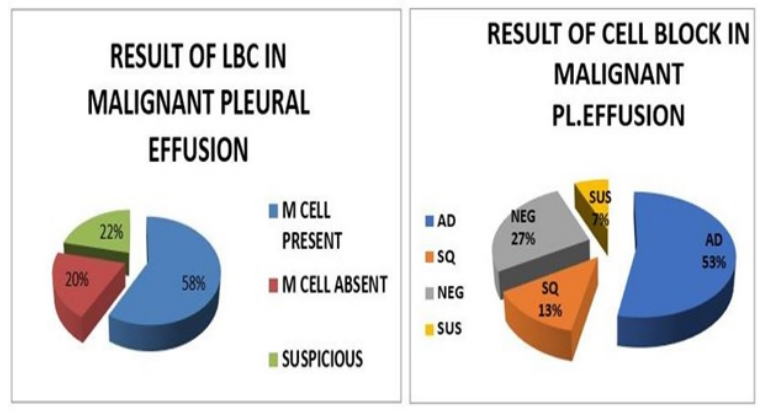

Figure-2 Shows Result of $L B C$ and CB in malignant pleural effusion.

TABLE-1: LIQUID BASED CYTOLOGY (LBC) IN MALIGNANT PLEURAL EFFUSION $(n=60)$

\begin{tabular}{|l|l|l|}
\hline \multicolumn{1}{|c|}{ LBC INTERPRETATION } & NO. OF PATIENT & PERCENTAGE \\
\hline M -CELL PRESENT & 35 & $58 \%$ \\
\hline M-CELL ABSENT & 12 & $20 \%$ \\
\hline SUSPICIOUS & 13 & $22 \%$ \\
\hline
\end{tabular}

In the present study liquid-based cytology was positive for malignancy in $58 \%$ cases( 35 cases out of 60 ) and suspicious of malignancy in $22 \%$ cases ( 13 cases out of 60 ), it had $95.35 \%$ sensitivity, $58.82 \%$ specificity in diagnosing malignant pleural effusion.(Figure-2,Table-1,3)

TABLE-2: PLEURAL FLUID CELL BLOCK (CB) IN MALIGNANT PLEURAL EFFUSION $(n=60)$

\begin{tabular}{|l|l|l|}
\hline PLEURAL FLUID CELL BLOCK & NO. OF PATIENT & PERCENTAGE \\
\hline POSITIVE (ADENO) & 32 & $53 \%$ \\
\hline POSITIVE (SQUAMOUS) & 8 & $13 \%$ \\
\hline NEGATIVE & 16 & $27 \%$ \\
\hline SUSPICIOUS & 4 & $7 \%$ \\
\hline
\end{tabular}

TABLE-3: DIAGNOSTIC YIELD OF LIQUID BASED CYTOLOGY (LBC) AND CELL BLOCK STUDY IN CASES OF MALIGNANT PLEURAL EFFUSION 


\begin{tabular}{|l|l|l|}
\hline \multicolumn{2}{|c|}{ LIQUID BASED CYTOLOGY } & \multicolumn{1}{c|}{ CELL BLOCK STUDY } \\
\hline SENSITIVITY & $95.35 \%$ & $100 \%$ \\
\hline SPECIFICITY & $58.82 \%$ & $94.12 \%$ \\
\hline POSITIVE PREDICTIVE VALUE & $85.42 \%$ & $97.7 \%$ \\
\hline NEGATIVE PREDICTIVE VALUE & $83.33 \%$ & $100 \%$ \\
\hline DIAGNOSTIC ACCURACY & $85 \%$ & $98.3 \%$ \\
\hline
\end{tabular}

Among 60 cell block samples $66 \%$ were positive for malignancy (53\% Adenocarcinoma and 13\% Squamous cell carcinoma) and $7 \%$ was suspicious for malignancy and it had $100 \%$ sensitivity, $94.12 \%$ specificity in diagnosing malignant pleural effusion. (Table-2,3)

TABLE-4: COMPARISON OF LIQUID BASED CYTOLOGY (LBC) AND CELL BLOCK STUDY RESULTS (CB) $(N=60)$

\begin{tabular}{|c|c|c|c|}
\hline & \multirow[t]{2}{*}{ LBC } & \multicolumn{2}{|c|}{ PL. FLUID CB } \\
\hline & & NEGATIVE & POSITIVE \\
\hline $35(100 \%)$ & M CELL PRESENT & $2(5.7 \%)$ & $33(94.3 \%)$ \\
\hline $12(100 \%)$ & M CELL ABSENT & $10(83.3 \%)$ & $2(16.7 \%)$ \\
\hline $13(100 \%)$ & SUSPICIOUS & $4(30.8 \%)$ & $9(69.2 \%)$ \\
\hline $60(100 \%)$ & TOTAL & $16(26.7 \%)$ & $44(73.3 \%)$ \\
\hline
\end{tabular}

In total 60 cases cell blocks were prepared from the residual fluid sample after doing liquid-based cytology. Among these in 44 cases were positive of malignancy for cell block (73.3\%) and $26.7 \%$ cell blocks were negative. Specificity and sensitivity for LBC was $95.35 \%$ and $58.82 \%$ whereas in the cell block study (CB) it was $100 \%$ and $94.12 \%$ respectively (Table-3). So, the cell block (CB)study was more sensitive and specific than liquid-based cytology (LBC). (Table-4)

TABLE-5: IMMUNOHISTOCHEMISTRY (TTF 1) WITH DIAGNOSIS $(\mathbf{N}=44)$

\begin{tabular}{|l|l|l|l|l|l|l|}
\hline \multicolumn{5}{|c|}{} & \multicolumn{5}{c|}{ DIAGNOSIS } & \multirow{2}{*}{ Total } \\
\cline { 2 - 7 } & ADENO CA & INFLAM. & MALIG (NOS) & SQUAM. CA & \\
\hline \multirow{2}{*}{$\pi F 1$} & Negative & 0 & 1 & 2 & 8 & 11 \\
\cline { 2 - 6 } & Positive & $33(75 \%)$ & 0 & 0 & 0 & 33 \\
\hline Total & 33 & 17 & 2 & 8 & 44 & \\
\hline
\end{tabular}

Immunohistochemistry (TTF-1) was done in 44 cases and among them 33 cases (75\%) were positive i.e. adenocarcinoma. Those cases were previously diagnosed as adenocarcinoma in the $C B$ study. (Table-5)

TABLE-6: IMMUNOHISTOCHEMISTRY (NAPSIN A) WITH DIAGNOSIS $(\mathrm{N}=44)$

\begin{tabular}{|c|c|c|c|c|c|c|}
\hline & \multicolumn{4}{|c|}{ DIAGNOSIS } & \multirow[t]{2}{*}{ Total } \\
\hline & & ADENO CA & INFLAM. & MALIG (NOS) & SQUAM. CA & \\
\hline \multirow[t]{2}{*}{ NAPSIN A } & Negative & 0 & 1 & 2 & 8 & 11 \\
\hline & Positive & $33(75 \%)$ & 0 & 0 & 0 & 33 \\
\hline
\end{tabular}

\begin{tabular}{|l|l|l|l|l|l|}
\hline Total & 33 & 17 & 2 & 8 & 44 \\
\hline
\end{tabular}

Immunohistochemistry (NAPSIN A) was done in44 cases and among them 33 cases (75\%) were positive i.e. adenocarcinoma. (Table-6)

TABLE-7: IMMUNOHISTOCHEMISTRY WITH DIAGNOSIS $(\mathbf{N}=44)$

\begin{tabular}{|c|c|c|c|c|c|c|}
\hline & \multicolumn{4}{|c|}{ DIAGNOSIS } & \multirow[t]{2}{*}{ Total } \\
\hline & & ADENO CA & INFLAM. & MALIG (NOS) & SQUAM. CA & \\
\hline \multirow[t]{2}{*}{$P-40$} & Negative & 33 & 1 & 2 & 0 & 36 \\
\hline & Positive & 0 & 0 & 0 & 8 & 8 \\
\hline Total & 33 & 17 & 2 & 8 & 44 & \\
\hline
\end{tabular}

Immunohistochemistry ( $\mathrm{P}-40)$ was done in 44 cases and among them 36 cases were negative and 8 cases were positive, provisionally diagnosed as squamous cell carcinoma in the CB study. (Table-7, Table-2).

\section{Discussion}

In normal conditions, the pleural space contains a small amount of pleural fluid [27]. Interpreting pleural fluid specimens is often a challenging task. In benign conditions, the cytological presentation is usually that of moderate cellularity, showing only scant mixed inflammatory cells and benign mesothelial elements, or a predominance of specific leukocytes [10].

According to Noppen et al, [11]. the volume of pleural fluid is $0.26 \pm 0.1 \mathrm{~mL} / \mathrm{kg}$ in human subjects and contains approximately $1.7 \times 10 \quad 3$ cells $/ \mathrm{ml}$, comprising approximately 75 percent macrophages, 23 percent lymphocytes, less than 3 percent polymorphonuclear cells and approximately 2 percent free mesothelial cells. Cancer cells in effusion fluids having markedly enlarged nuclei, irregular nuclear contours and a cytoplasm texture that is frothier and less dense than that of most mesothelial cells (Figure-3).

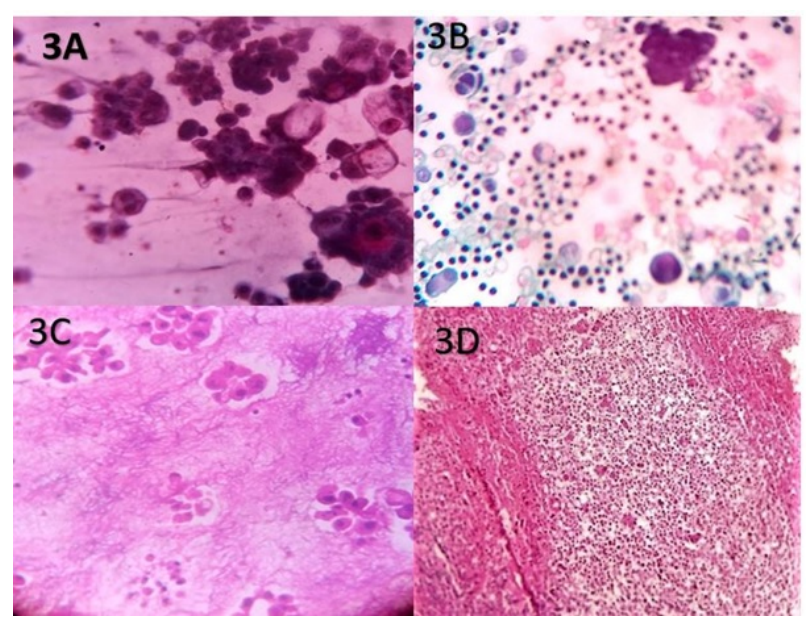


Figure-3: (A) Liquid based cytology (Ibc) picture: 3d cluster (x400),(b)Pleural fluid lbc: cell canabolism with $3 d$ cluster seen (H\&E stain, x400), (c) Pleural fluid cell block: adenocarcinoma(H\&E stain, x400), (d) Pleural fluid cell block: adenocarcinoma (H\&E stainx100)

Discriminating malignant cells from reactive mesothelial cells and macrophages in the pleural fluid are challenging only by LBC. According to Theerada Assawasaksakul et al. cytological examination is one of the most useful examinations when malignancy is suspected and the cell block (CB) technique of the pleural fluid may augment the diagnostic utility [12]. Chang Gok Woo et al. said analysis of cell block preparation (CB) along with liquid-based cytology (LBC) and carcinoembryonic antigen (CEA) showed a convincing diagnostic performance especially in cases in which malignancy is suspected or those showing equivocal cytological features [13]. According to M Bhanvadia Viral et al. the main advantages of the $C B$ technique are the preservation of tissue architecture and obtaining multiple sections for special stains and immunohistochemistry [14]. According to George R. Collins the cell block (CB) from bronchial washing in addition to liquid-based cytology (LBC) improves the rate of detection of malignancy over the use of LBC or cell block alone [15].

According to Yunfan Ma et al. Non-Small Cell Lung Cancer (NSCLC) accounts for $80 \%$ of lung cancer and adenocarcinoma is one of the main types of NSCLC. Patients with the high expression level of thyroid transcription factor 1 (TTF-1) and Napsin $A$ and high co-expression level of TTF-1/Napsin $A$ had better survival rates than those with low levels of expression [16]. According to Ye J, Findeis-Hosey J] et al. Napsin A and TTF1positive immunostaining are highly specific for primary adenocarcinoma of the lung and the combination of these two biomarkers are helpful for segregation of primary lung adenocarcinoma from metastatic carcinoma of the lung [17]. According to Tatsumori T1, Tsuta $\mathrm{K}$ et al,.P -40 immunostaining yields high sensitivity and high specificity for distinguishing squamous cell carcinoma (SCC) from adenocarcinoma, neuroendocrine carcinoma and malignant mesothelioma [18]. According to Travis WD et al. p40 immunostain has high sensitivity and specificity for identifying lung squamous cell carcinomas on the FNA cell-block materials, which might be superior to p63 immunostain in the subtyping of
NSCLCs [19]. Chen Zhang et al. A panel of immunohistochemical (IHC) stains frequently used to subclassify non-small cell lung cancers include NapsinA, TTF1, CK-5/6, P40 and P63.
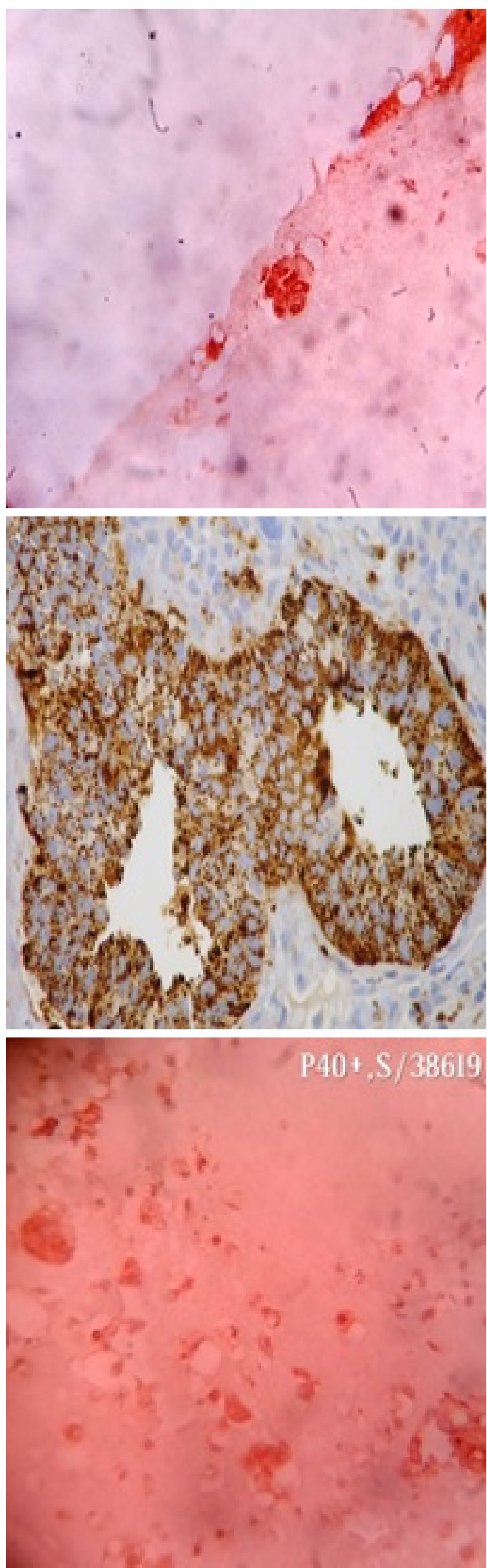
Figure-4: (A) Pleural fluid cell block: ttf1: positive in adenocarcinoma,(B) Pleural fluid cell block: napsin a positive in adenocarcinoma,(C) Pleural fluid cell block: p40 positive in squamous cell carcinoma.

The expression profile of these stains in the neuroendocrine tumor has not been systemically evaluated [20]. According to Ming-Hui Ao, et al.the combination of TTF1/Napsin A/P40 panel is costeffective and could conserve valuable tumor tissue during the immunohistochemical study and for subclassification of non-small cell lung carcinoma. In this study the sensitivity and specificity of the triple marker showed $\mathbf{9 3 . 5 0 \%}$ and $\mathbf{7 7 . 5 \%}$ for primary lung adenocarcinoma [21]. In our study Cell block preparation was done from the residual fluid specimen after LBC preparation and

Studied further by Immunohistochemistry (TTF -1, Napsin A and P-40). (Figure-4A, B, C).

In the present study most of the study population were in between the age group of 51 to 60 years, 54.46+_13.39 (mean +_ standard deviation) and male: female ratio was 2:1 presented with fever $(85 \%)$, cough $(83 \%)$, chest pain $(80 \%)$. Haidari B et al study [22]. and Fa al-alusi study [23] showed similar symptomatology.

Table - 8: Comparison of Age And Sex Incidences of Our Study With The Other Studies

\begin{tabular}{|l|l|l|}
\hline \multicolumn{1}{|c|}{ Name of Study } & \multicolumn{1}{|c|}{ Mean Age / Age Group } & \multicolumn{1}{|c|}{$\begin{array}{c}\text { Male To Female } \\
\text { Ratio }\end{array}$} \\
\hline $\begin{array}{l}\text { Hierholzer J et al } \\
{[24]}\end{array}$ & 55.9 & $1.6: 1$ \\
\hline Valdès L et al [25] & 57.1 & $1.66: 1$ \\
\hline $\begin{array}{l}\text { Liangping L et al. } \\
{[26]}\end{array}$ & 58.7 & $1.46: 1$ \\
\hline Present study & $\begin{array}{l}51-60 \text { yrs. (mean } \\
54.46 y e a r s)\end{array}$ & $2: 1$ \\
\hline
\end{tabular}

In the present study most of the study population were in between the age group of 51 to 60 years, 54.46+_13.39 (mean +_ standard deviation) and male: female ratio was $2: 1$. This is quite similar to the other study shown in table 8 . Cell blocks were prepared in 60 cases from the residual pleural fluid sample after liquid-based cytology. Among these in 44 cases were positive for malignancy in cell block preparation (73.3\%). So, the sensitivity was $100 \%$ and specificity $94.12 \%$ which showed both sensitivity and specificity increased in cell block than LBC.
The result was consistent with Ghosh I et al. study [27]. who reported $82 \%$ sensitivity of cell block technique in diagnosing malignant pleural effusion In the Thapar $M$ et al. study simultaneous use of the cell block technique and smear examination increased diagnostic accuracy by $13.0 \%$ [28].

Table- 9 Comparison of Diagnostic Yield of Liquid Based Cytology of Our Study With The Other Studies

\begin{tabular}{|l|l|l|l|}
\hline \multirow{2}{*}{\multicolumn{1}{|c|}{ Studies }} & \multicolumn{3}{c|}{ Liquid-Based Cytology } \\
\cline { 2 - 4 } & Sensivity & Specificity & Diag. Accuracy \\
\hline Present Study & $95.35 \%$ & $58.82 \%$ & $85 \%$ \\
\hline Chang Gok Woo et al. [29] & $81.3 \%$ & $99.4 \%$ & \\
\hline Saswati Pal et al. [30] & $100 \%$ & $76 \%$ & $80 \%$ \\
\hline
\end{tabular}

In the present study liquid-based cytology (LBC) was positive for malignancy in $58 \%$ of cases and suspicious of malignancy in $22 \%$ of cases of malignant pleural effusion and it had $95.35 \%$ sensitivity, $58.82 \%$ specificity in diagnosing malignant pleural effusion. This is quite similar to the other study shown in table 9. Cytological examination of pleural fluid was one of the commonly performed examinations and it is not only important in diagnosis but also necessary for staging and prognosis. The diagnostic performance of liquid-based cytology (LBC) of pleural fluid may be attributable to the fact that the cell population present in sediment was representative of a larger surface area and on the other hand cell block study was simple, inexpensive and not required any special training or instrument. Morphological features were better identified by the cell block method when compared to LBC. Multiple sections can be obtained if required for a special stain or IHC study. It bridges the gap between cytology and histology.

\section{Conclusion}

Morphological features were better identified by the cell block method when compared to LBC It bridges the gap between cytology and histology. Immunohistochemistry should be integrated with liquid-based cytology in routine clinical practice to improve the diagnostic accuracy of malignant pleural effusion especially in cases where malignancy is suspected or those showing the equivocal result.

\section{What does this study add to existing knowledge?}


Cytological examination of pleural fluid was one of the commonly performed examinations and it is not only important in diagnosis but also necessary for staging and prognosis. Morphological features were better identified by the cell block method when compared to LBC. Multiple sections can be obtained if required for a special stain or IHC study. This is a combined study of LBC, Cellblock and IHC which bridges the gap between cytology and histology and to help the clinician for proper diagnosis of malignancies and to treat the patient early.

\section{Author Contribution}

1st Author: Idea of the study, Editing, Reference collection, IHC Study, Result analysis.

2nd Author: LBC and cell block preparation, Data collection, Manuscript writing, Result analysis.

Corresponding Author: IHC study, Manuscript writing, Editing, Result analysis.

\section{Reference}

01. Sahn SA. Malignancy metastatic to the pleura. Clin Chest Med. 1998 Jun;19(2)351-61. doi: 10.1016/s0272-5231(05)70082-4 [Crossref] [PubMed][Google Scholar]

02. Matthay RA, Coppage L, Shaw C, Filderman AE. Malignancies metastatic to the pleura. Invest Radiol. 1990 May;25(5)601-19. doi: 10.1097/00004424199005000-00025 [Crossref][PubMed][Google Scholar]

03. Leuallen Ec, Carr Dt. Pleural effusion; a statistical study of 436 patients. N Engl J Med. 1955 Jan $20 ; 252(3) 79-83$.

doi:

10.1056/NEJM195501202520301

[Crossref]

[PubMed][Google Scholar]

04. Light RW, Macgregor MI, Luchsinger PC, Ball WC Jr. Pleural effusions- the diagnostic separation of transudates and exudates. Ann Intern Med. 1972 Oct;77(4)507-13. doi: 10.7326/0003-4819-77-4507 [Crossref][PubMed][Google Scholar]

05. Heffner JE, Brown LK, Barbieri CA. Diagnostic value of tests that discriminate between exudative and transudative pleural effusions. Primary Study Investigators. Chest. 1997 Apr;111(4)970-80. doi: 10.1378/chest.111.4.970 [Crossref][PubMed]
06. Bishop JA, Teruya-Feldstein J, Westra WH, Pelosi G, Travis WD, Rekhtman N. p40 $(\Delta N p 63)$ is superior to $\mathrm{p} 63$ for the diagnosis of pulmonary squamous cell carcinoma. Mod Pathol. 2012 Mar;25(3)405-15. doi: 10.1038/modpathol.2011.173 [Crossref][PubMed] [Google Scholar]

07. Nonaka D. A study of $\Delta \mathrm{Np63}$ expression in lung non-small cell carcinomas. Am J Surg Pathol. 2012 Jun;36(6)895-9. doi: 10.1097/PAS.0b013e3182498f2b [PubMed][Google Scholar]

[Crossref]

08. Nobre AR, Albergaria A, Schmitt F. p40- a p63 isoform useful for lung cancer diagnosis - a review of the physiological and pathological role of p63. Acta Cytol. 2013;57(1)1-8. doi: 10.1159/000345245 [Crossref][PubMed][Google Scholar]

09. Leuallen Ec, Carr Dt. Pleural effusion; a statistical study of 436 patients. N Engl J Med. 1955 Jan 20;252(3)79-83. doi: 10.1056/NEJM195501202520301 [Crossref] [PubMed][Google Scholar]

10. Light, Richard W, YC Gary Lee, eds. Textbook of Pleural Diseases Second Edition. CRC Press. 2008. [Crossref][PubMed][Google Scholar]

11. Noppen M, De Waele M, Li R, Gucht KV, D'Haese J, Gerlo E, et al. Volume and cellular content of normal pleural fluid in humans examined by pleural lavage. Am J Respir Crit Care Med. 2000 Sep;162(3 Pt 1)1023-6. doi: 10.1164/ajrccm.162.3.9910050 [Crossref][PubMed][Google Scholar]

12. Chen YS, Lee JM, Chao YK. Introduction- 2017 Taiwan Association of Thoracic \& Cardiovascular Surgery. J Thorac Dis. 2017 Oct;9(Suppl 14)S1397S1398. doi: 10.21037/jtd.2017.10.133 [Crossref] [PubMed][Google Scholar]

13. Thapar M, Mishra RK, Sharma A, Goyal V, Goyal V. Critical analysis of cell block versus smear examination in effusions. J Cytol. 2009 Apr;26(2)60-4. doi: 10.4103/0970-9371.55223 [Crossref][PubMed][Google Scholar]

14. Shivakumarswamy $U$, Arakeri SU, Karigowdar $\mathrm{MH}$, Yelikar B. Diagnostic utility of the cell block method versus the conventional smear study in pleural fluid cytology. J Cytol. 2012 Jan;29(1)11-5. doi: 10.4103/0970-9371.93210 [Crossref][PubMed] [Google Scholar] 
15. Karahalli $E$, Yilmaz A, Türker $H$, Ozvaran $K$. Usefulness of various diagnostic techniques during fiberoptic bronchoscopy for endoscopically visible lung cancer- should cytologic examinations be performed routinely?. Respiration. 2001;68(6)6114. doi: 10.1159/000050581 [Crossref][PubMed] [Google Scholar]

16. Ma $Y$, Fan $M$, Dai $L$, Kang $X$, Liu $Y$, Sun $Y$, et al. The expression of TTF-1 and Napsin A in early-stage lung adenocarcinoma correlates with the results of surgical treatment. Tumor Biol. 2015 Sep;36(10)8085-92. doi: 10.1007/s13277-0153478-z [Crossref][PubMed][Google Scholar]

17. Yetkin O, Tek I, Yetkin F, Numanoglu N. Role of pleural viscosity in the differential diagnosis of exudative pleural effusion. Respirology. 2007 Mar;12(2)267-71. doi: 10.1111/j.14401843.2006.01041.x [Crossref][PubMed][Google Scholar]

18. Jolobe OM. Atypical tuberculous pleural effusions. Eur J Intern Med. 2011 Oct;22(5)456-9. doi: 10.1016/j.ejim.2011.03.011 [Crossref] [PubMed][Google Scholar]

19. Zhang C, Schmidt LA, Hatanaka K, Thomas D, Lagstein A, Myers JL. Evaluation of napsin A, TTF-1, p63, p40, and CK5/6 immunohistochemical stains in pulmonary neuroendocrine tumors. Am J Clin Pathol. 2014 Sep;142(3):320-4. doi: 10.1309/AJCPGAOIUA8BHQEZ [Crossref][PubMed] [Google Scholar]

20. Author Manuscript. Table 1. Hum Pathol. 2014 May; 45(5)926-934. doi: 10.1016/j.humpath.2014.01.005 [Crossref] [PubMed][Google Scholar]

21. Heidari B, Bijani K, Eissazadeh M, Heidari P. Exudative pleural effusion: effectiveness of pleural fluid analysis and pleural biopsy. East Mediterr Health J. 2007 Jul-Aug;13(4):765-73. [Crossref] [PubMed][Google Scholar]

22. Al-Alusi F. Pleural effusion in Iraq- a prospective study of 100 cases. Thorax. 1986 Jun;41(6)492-3. doi: 10.1136/thx.41.6.492 [Crossref][PubMed] [Google Scholar]

23. Hierholzer J, Luo L, Bittner RC, Stroszczynski C, Schröder RJ, Schoenfeld N, et al. MRI and CT in the differential diagnosis of pleural disease. Chest. 2000 Sep;118(3)604-9. doi: 10.1378/chest.118.3.604 [Crossref][PubMed][Google Scholar]
24. Valdés L, Alvarez D, Valle JM, Pose A, San José $E$. The etiology of pleural effusions in an area with high incidence of tuberculosis. Chest. 1996 Jan;109(1)158-62. doi: 10.1378/chest.109.1.158 [Crossref][PubMed][Google Scholar]

25. Luo L, Hierholzer J, Bittner RC, Chen J, Huang L. Magnetic resonance imaging in distinguishing malignant from benign pleural disease. Chin Med J (Engl). 2001 Jun;114(6)645-9. [Crossref][PubMed] [Google Scholar]

26. Ghosh I, Dey SK, Das A, Bhattacharjee D, Gangopadhyay S. Cell block cytology in pleural effusion. J Indian Med Assoc. 2012 Jun;110(6)3902, 396. [Crossref][PubMed][Google Scholar]

27. Thapar M, Mishra RK, Sharma A, Goyal V, Goyal V. Critical analysis of cell block versus smear examination in effusions. J Cytol. 2009 Apr;26(2)60-4. doi: 10.4103/0970-9371.55223 [Crossref][PubMed][Google Scholar]

28. Woo CG, Son SM, Han HS, Lee KH, Choe KH, An JY, et al. Diagnostic benefits of the combined use of liquid-based cytology, cell block, and carcinoembryonic antigen immunocytochemistry in malignant pleural effusion. J Thorac Dis. 2018 Aug;10(8)4931-4939. doi: 10.21037/jtd.2018.07.139 [Crossref][PubMed] [Google Scholar]

29. Daudu O U, et al. Comparison of HIV Screening Methods of Donor Blood Using Rapid Fourth Generation Elisa Assay in Kaduna, Nigeria. IOSR Journal of Dental and Medical Sciences (IOSRJDMS). 2017;16; Ver VI (5)34-35. [Crossref] [PubMed][Google Scholar] 